\title{
Triploidy in tambaqui Colossoma macropomum identified by chromosomes of fish larvae
}

\begin{abstract}
Triploid fish are excellent models for use in commercial scale because they can show higher rates of growth, carcass yield and meat quality. If sterile, tambaqui (Colosso mamacropomum) triploids can be used to avoid the problems related to early puberty, especially the negative impacts of male sexual maturation on harvest weight. In the present study, we evaluated the triploidy induction efficiency (thermal shocks) in the fish tambaqui Colossoma macropomum, the most important Neotropical species used for aquaculture. To verify the result of the triploidy experiments, we used a protocol of ploidy identification through analysis of mitotic chromosomes of early life stages (larvae cytogenetics). We obtained better results of hatching and triploid rates through temperature shock at $41^{\circ} \mathrm{C}$ for 2 min (heat shock) than cold shock. In conclusion, additional treatments will allow to refine the protocols to obtain $100 \%$ of triploidy in tambaqui, particularly those from heat shocks. These methodologies can also be applied to other Neotropical fish species, as alternative methods for breeding programs and to delineate conservation plans for the proper management of the stocks.
\end{abstract}

Keywords: triploid, fish genetics, chromosome manipulation, aquaculture
Volume 9 Issue 3 - 2020

\author{
Lucas S. Sato,' Paulo H Jorge, ' Vito A \\ Mastrochirico-Filho,' Milene E Hata,' Sergio \\ R Batlouni,' Rafael Y Kuradomi,' Fábio \\ Porto-Foresti, ${ }^{2}$ Fausto Foresti, ${ }^{3}$ Diogo T. \\ Hashimoto \\ ISão Paulo State University (Unesp), Aquaculture Center of \\ Unesp, Brazil \\ ${ }^{2}$ São Paulo State University (Unesp), School of Sciences, Brazil \\ ${ }^{3}$ São Paulo State University (Unesp), Institute of Biosciences, \\ Brazil
}

Correspondence: Diogo Hashimoto,Aquaculture Center of Unesp,Via de Acesso Prof. Paulo Donato Castellane, s/n, | 4884-900 Jaboticabal/SP, Brazil,Tel +55 I6 3209-7477, Email diogo.hashimoto@unesp.br

Received: April 30, 2020 | Published: May 07, 2020

\section{Introduction}

The tambaqui Colossoma macropomum Cuvier, 1818 is included in the family Serrasalmidae (Teleostei, Characiformes) occupying a wide distribution in the Amazon and Orinoco basins. ${ }^{1}$ This native species represents the major production value in Brazilian fish farms, especially in North, Northeast and Midwest regions of Brazil. In the period 2003-2009, the production of tambaqui grown up 123\%, ${ }^{2}$ and reached 136,991tonnes in 2016. ${ }^{3}$ Tambaqui is also used for crossings with other Serrasalmidae species (pacu Piaractus mesopotamicus and pirapitinga Piaractus brachypomus), resulting in interspecific hybrids, which are widely used in the Midwest and Southeast regions of Brazil. ${ }^{4}$ Thus, the production of tambaqui has contributed more than $55 \%$ in relation to the aquaculture of native species in $\mathrm{Brazil}^{3}$ and has presented increased production records in other Latin American countries. ${ }^{5}$

In addition to its nutritional flesh quality, market acceptance, zootechnical characteristics and favorable adaptations to fish farming systems, the increment of tambaqui production is especially due to advances in varied scientific researches. ${ }^{6}$ As it is considered a target species for breeding programs, development of genetic studies has been performed in order to increase production. ${ }^{7,8}$ In relation to chromosome manipulations for fish production, several techniques began to affect the global industry only during the 1980s and 1990s, especially because of triploids produced on a large scale for trout, salmon and carp. ${ }^{9}{ }^{10}$ Triploidy induction usually makes the fish sterile and has been found to be useful for improving growth rates in mature fish, with better processing yield and flesh quality. ${ }^{11,12}$ In relation to tambaqui, this technique could be useful to solve the problem associated to early puberty, particularly the negative impacts of male sexual maturation on harvest weight. ${ }^{13}$

Triploidy is induced by normal fertilization followed by a process that force the retention of the second polar body, by means of thermal shock, hydrostatic pressure, even chemicals (colchicine and cytochalasin) which are briefly applied after fertilization. ${ }^{12}$ The success of polyploidy induction depends on the time of the shock, its duration, the temperature, and the quality of the eggs. ${ }^{14}$ In this process, several experiments to standardization and efficient tests that assess the ploidy level are required to ensure $100 \%$ of triploid. Methods to detect the ploidy level can be characterized into direct method, such as chromosome number count (karyotyping); or indirect, such as nuclear or cell size measurement, measurement of the DNA content, microsatellite genotyping and analysis of the nucleolus organizer regions (NOR). ${ }^{12}$ Cytogenetic of early life stages of fish (e.g. larvae) is a simple, reliable and low-cost method to verify the ploidy level of triploidization experiments. Thus, the objective of this study was to perform a triploidy induction experiment in tambaqui by thermal shocks (heat and cold), evaluating hatching and triploid rates.

\section{Materials and methods}

\section{Breeding protocol}

One female and three males of tambaqui C. macropomum were used for the breeding experiments and triploidization tests. These animals belong to the breeding stock of the Aquaculture Center of UNESP (CAUNESP), Jaboticabal, SP, Brazil. All experiments were conducted according to the animal welfare guidelines, approved by the Ethics Committee on Animal Use (CEUA), of the Faculty of Agricultural and Veterinary Sciences, UNESP, Campus of Jaboticabal (Protocol number 7924/15). The animals used for breeding were anaesthetized with benzocaine $(100 \mathrm{mg} / \mathrm{l})$. The fish larvae used for ploidy analysis were euthanized with benzocaine overdose $(500 \mathrm{mg} / \mathrm{l})$.

The spawning induction was performed using the carp pituitary extract (CPE), dissolved in saline solution $(0.9 \% \mathrm{NaCl})$ and applied intramuscularly in two doses $(0.6$ and $5.4 \mathrm{mg} / \mathrm{kg}$ with a $12 \mathrm{~h}$ interval for females). At the same time of the second dose, $5 \mathrm{ml}$ of synthetic prostaglandin (Ciosin ${ }^{\circledR}$ containing $0.25 \mathrm{mg} / \mathrm{mL}$ cloprostenol, Schering-Plough Saúde Animal Ind. Com. Ltda., Campinas, SP, Brazil) was also applied according to the protocol described by Criscuolo-Urbinati et al. (2012). For males, a single CPE dose (1.5mg/ 
$\mathrm{kg}$ ) was used at the same time of the second dose to females. Gametes were collected after 240 degree-hours.

\section{Triploidy experiment}

We tested different thermal shocks (heat and cold shocks) in the tambaqui eggs. Initially, each treatment (3 replicates) was composed of $5 \mathrm{ml}$ of oocytes ( 1 female) and $50 \mu 1$ of sperm (resultant pool of 3 males), activated with $500 \mathrm{ml}$ of water at $28^{\circ} \mathrm{C}$ for $1 \mathrm{~min}$. The water used in the gametes activation was discarded and the newly fertilized eggs were subjected to the thermal shock. The heat shock treatment was performed at $41^{\circ} \mathrm{C}$ for $2 \mathrm{~min}$, while the cold shock was carried out at $6^{\circ} \mathrm{C}$ during $10 \mathrm{~min}$. Finally, the eggs were transferred to hatcheries and kept at $28^{\circ} \mathrm{C}$. A control treatment was used without thermal shock, whose fertilization occurred at $28^{\circ} \mathrm{C}$.

To determine the hatching rate, 100 embryos were randomly collected and counted $17 \mathrm{~h}$ post fertilization (before the larvae hatching), excluding deformed embryos. After hatching, the larvae were maintained in hatcheries for 7 days, and then they were transferred to tanks $(100 \mathrm{l})$ at $28^{\circ} \mathrm{C}$, with constant water flow $(2 \mathrm{l} / \mathrm{min})$. For ploidy verification, 16 larvae were examined cytogenetically in each treatment, and then the chromosomes of 30 metaphases were counted for each larva.

\section{Obtaining mitotic chromosomes of fish larvae}

The larvae of C. macropomum were incubated in a solution of colchicine $(0.007 \%)$ for $4 \mathrm{~h}$. After the incubation in colchicine, the larvae were individually sacrificed and totally dissociated in Petri dishes containing $7 \mathrm{ml}$ of hypotonic $\mathrm{KCl}$ solution $(0.075 \mathrm{M})$.Then, the cell suspension was transferred to centrifuge tubes $(15 \mathrm{ml})$ and kept at $37^{\circ} \mathrm{C}$ for $21 \mathrm{~min}$. The following steps were similar to the standard protocol of cell fixation (solution of 3:1 methanol and acetic acid, respectively). ${ }^{15}$ Each slide was standardized with two drops of $20 \mu \mathrm{L}$ of chromosome preparation and stained with Giemsa 5\%.

\section{Detection of nucleolus organizer regions (NORs)}

In order to get indirect cytogenetic markers for triploidy detection, we analyzed the chromosomes bearing nucleolus organizer regions (NOR) by silver nitrate staining. In this case, the NOR number in interphase nucleus could characterize the quantity of chromosome sets (ploidy level) in individuals subject to triploidization as has been performed for some fish species. The procedure followed the technique originally described by Howell and Black. ${ }^{16}$

\section{Image analysis}

The metaphases were photographed by a CCD camera (Leica DFC310FX), mounted in a microscope Leica DM4000. The images were captured and processed by the Leica LAS software v4.3.0. The chromosomes were isolated using Adobe Photoshop Elements 6.0 software (Adobe Systems) for the karyotypes assembly. The chromosomes were classified as metacentric (m), submetacentric $(\mathrm{sm})$, subtelocentric (st) and acrocentric (a). ${ }^{17}$

\section{Results}

The hatching rate in the control treatment was $86 \%$. After the thermal shock treatment in tambaqui eggs, hatching rates of the cold and heat shocks were of $57.3 \%$ and $85.7 \%$, respectively (Table 1 ). In addition, abnormalities in the embryonic development were observed when performing cold shock in the eggs (data not quantified).

Table I Hatching and triploid rates of the experiments in tambaqui

\begin{tabular}{llllll}
\hline Treatment & Post fertilization time $(\mathbf{m i n})$ & Shock time $(\mathbf{m i n})$ & Temperature $\left({ }^{\circ} \mathbf{C}\right)$ & Hatching rate & Triploid rate \\
\hline cold & I & 10 & 6 & $57.3 \%$ & $5.8 \%$ \\
heat & I & 2 & 41 & $85.7 \%$ & $58.8 \%$ \\
control & - & - & 28 & $86.0 \%$ & 0 \\
\hline
\end{tabular}

For the control treatment, the results of larvae cytogenetic showed that all individuals were $2 \mathrm{n}$, with mitotic cells of 54 chromosomes, classified as $\mathrm{m}$ and $\mathrm{sm}$ (Figure 1a). Triploidization data were better in the heat shock than cold shock. When the eggs were exposed at $41^{\circ} \mathrm{C}$ for $2 \mathrm{~min}$ ( $1 \mathrm{~min}$ post fertilization), we obtained a frequency of $58.8 \%$ of triploid larvae, with $3 n=81$ chromosomes (Figure $1 b$ ). In the analysis of the treatment at $6^{\circ} \mathrm{C}$ for $10 \mathrm{~min}(1 \mathrm{~min}$ post fertilization), we identified only $5.8 \%$ of triploid larvae.
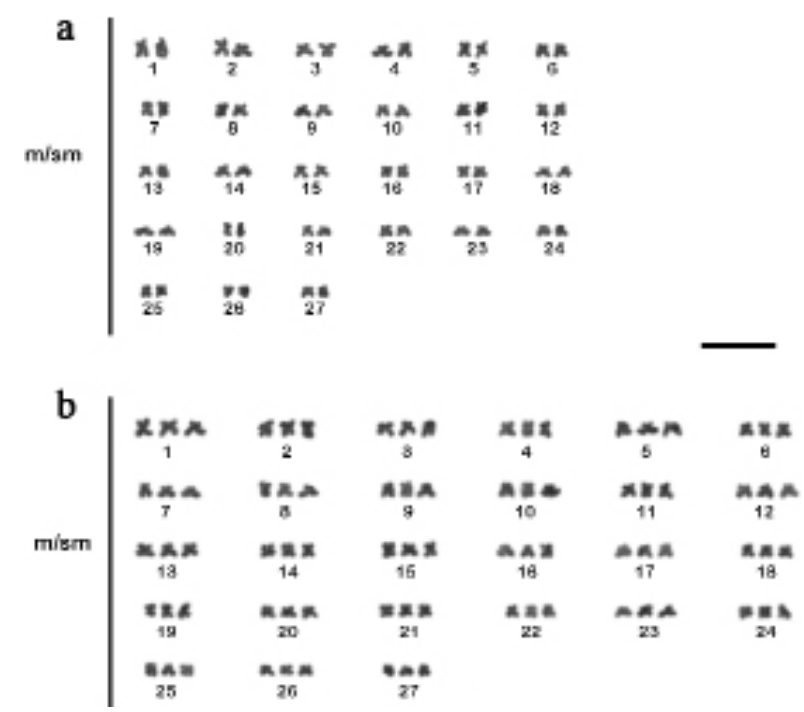

Figure I Karyotypes of tambaqui larvae. $2 n=54$ chromosomes $(\mathbf{a})$ and $3 n=8 I$ chromosomes $(\mathbf{b})$. Bar $=10 \mu \mathrm{m}$. 
Silver nitrate staining (AgNO3) showed intra-individual variation of chromosomes bearing NORs (multiple NOR). This characteristic of multiple NOR was present in diploid and triploid metaphases of tambaqui, particularly at the terminal regions of the long arm or short arm in some chromosomes (Figure 2a). In mitotic cells of diploid individuals of tambaqui, we found metaphases with 2 to 4 chromosomes bearing NOR sites. In triploid samples, we detected 2 to 5 NORs. Therefore, interphase nucleus analysis also showed a similar pattern of multiple NOR (Figure $2 b \& 2 c$ ), with intra-individual variation, which prevents the triploid detection by this simple and indirect method.
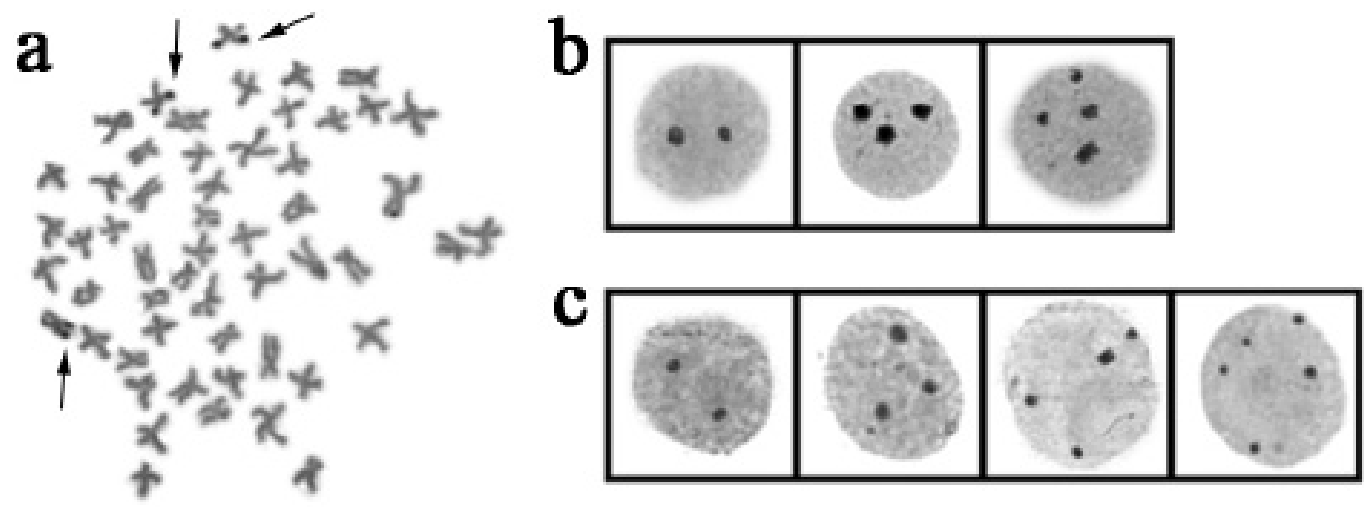

Figure 2 (a) metaphase of tambaqui diploid with 3 NOR sites (arrows), which is a situation that can lead to erroneous identification of triploid. Interphase nuclei stained with silver nitrate, revealing a variation of NOR numbers for diploid. (b) and triploid tambaqui (c).

\section{Discussion}

Diploid individuals of tambaqui showed 54 chromosomes, while triploid samples demonstrated the chromosome number of 81 . In previous cytogenetic studies, tambaqui was characterized by a diploid chromosome number of 54, showing chromosome morphologies of types metacentric and submetacentric, ${ }^{18,19}$ according to the results of the present study. However, NOR analysis by silver nitrate in interphase nuclei was not efficient to detect tambaqui triploids. This method is useful in cases of fish genomes with simple NOR (only one pair of NOR-bearing chromosomes), as in Rhamdia quelen, ${ }^{20}$ but situations with multiple NORs can lead to erroneous interpretations of the ploidy level. NORs represent chromosomes regions involved in the transcription of ribosomal genes that can be visualized after silver nitrate coloration when the genes present activities in the interphase that anticipates the mitosis. ${ }^{21,22}$ Thus, silver nitrate staining detects only active NORs, since it stains not the rDNA but rather a set of acidic proteins associated with the process of ribosome production. ${ }^{23,24}$ This fact explains the intra-individual variability of NOR sites between different cells analyzed.

The critical values of polyploidy induction by thermal shocks for each variable (timing, intensity and duration) are species-specific and optimization is needed to obtain the highest triploid yield. ${ }^{25,26}$ Apparently, thermal shocks could vary depending on the natural conditions of the species, i.e., triploidy protocol in warm water species is more susceptible to cold shock, whereas in coldwater species is more effective with heat shock ${ }^{27,28}$. However, our results demonstrated that the heat shock was better than cold shock in tambaqui (considered as warm water species), both in the hatching and triploid rates.

Nevertheless, as $100 \%$ triploidy was not yet achieved in our experiments, further studies are needed to refine the triploidy protocols in tambaqui, with major focus on heat shocks. Several standardization tests can be performed, including post-fertilization time. Generally, for warmwater species, the shock can be applied up to 7 min postfertilization, and the temperature of the heat shock may range from 34 to $41^{\circ} \mathrm{C}$, with duration of $45 \mathrm{~s}$ to $3.5 \mathrm{~min}$; in cold temperatures, shock can range from -1 to $4^{\circ} \mathrm{C}$, with duration of 2 to $20 \mathrm{~min}$.
In the present study, tambaqui triploid fish from artificial induction with thermal shock was the main result obtained. Serrasalmid triploidy has already been detected spontaneously, mainly to interspecific hybrids, as the case of one individual of the hybrid tambacu ( tambaqui x $\widehat{O}$ pacu Piaractus mesopotamicus) (Almeida-Toledo et al., 1987), one post-F1 specimen resulting from backcrossing between क pacu x $\delta$ tambacu ( + tambaqui $\mathrm{x} \delta \mathrm{pacu}$ ) ${ }^{29}$ and another intergenus hybrid individual between $\phi$ patinga ( + pacu $\mathrm{x} \hat{\sigma}$ pirapitinga Piaractus brachypomus) $\mathrm{x}$ ô tambaqui. ${ }^{30}$

The occurrence of natural triploidy in Neotropical fish seems to be a phenomenon relatively frequent. This phenomenon have already been detected for different fish groups, such as Leporinus cf. elongatus (Characiformes, Anostomidae), Astyanax eigenmanniorum and Astyanax scabripinnis (Characiformes, Characidae), Characidium cf. zebra (Characiformes, Crenuchidae), Hoplerythrinus unitaeniatus (Characiformes, Erythrinidae), Gymnotus carapo (Gymnotiformes, Gymnotidae), Trichomycterus davisi (Siluriformes, Trichomycteridae), among others. ${ }^{31-36}$ In aquaculture, fish triploid induction for Neotropical species have been developed for jundiá Rhamdia quelen..$^{37-39}$ In these experiments, the protocols allow obtaining $100 \%$ of triploids. ${ }^{20,40}$ Therefore, jundia triploids could be used on a commercial scale because of the difficulties for largescale production of diploids, such as early sexual maturation and heterogeneity in growth rate..$^{41,42}$

For this reason, triploidy in tambaqui should also be further exploited in Brazilian fish farming because it can provide benefits to increase production of the main native species in aquaculture, since triploid fish have potential for higher growth rates, carcass yield and meat quality. ${ }^{12}$ Chiefly, if sterile, tambaqui triploids could be attempted to solve the problems of early puberty of males which has negatively influenced harvest weight. ${ }^{13}$ Furthermore, tambaqui is one of the main resources exploited by extractive fishing in Brazil. However, the natural stocks of tambaqui are already considered over-exploited or threatened mainly due to the high overfishing rate (Normative Instruction $n^{\circ} 05 / 2004$, Ministry of the Environment, Brazil). Thus, the use of genetic biotechnology in aquaculture is an alternative to 
supply the demand of the consumer market and a strategy to help reduce fishing pressure on wild populations of tambaqui.

Triploid fish are excellent models to be used for conservation purposes due to the sterility caused by erroneous pairing of the chromosome sets during the meiosis.For example, aquaculture of tambaqui in cages was recently permitted in the Tocantins-Araguaia basin in Brazil (Normative Instruction $n^{\circ}$ 9/2012, Ministry of the Environment, Brazil); however, tambaqui is originally from the Amazon basin and considered an allochthonous species in the Tocantins-Araguaia basin. In this latter basin, there is the natural occurrence of other serrasalmid species, Piaractus brachypomus. The problem arises due to escapes that will occur with the production of tambaquis in cages, breaking the geographical barrier between the two species, and thus enabling the formation of hybrid zones. This could generate a single population of hybrids, causing genetic introgression in the gene pool of the native species P. brachypomus. Therefore, the introduction of tambaqui triploid (instead of diploid) could be an alternative to solve this challenge. However, the sterility of tambaqui triploid still needs to be evaluated in further studies.

In accordance with the results of hatching and triploid rates, we concluded that heat shock has better performance than cold shock to produce triploids of tambaqui in large scale. Additional experiments will allow to improve the protocols to obtain $100 \%$ of triploidy in tambaqui, particularly those from heat shocks, which will represent an important biotechnology for sustainable aquaculture in South America.

\section{Acknowledgments \& Funding}

This work was supported by grants fromPró-Reitoria de Pesquisa da UNESP (Prope 07/2015), Conselho Nacional de Desenvolvimento Científico e Tecnológico (CNPq 010207/2013-9), and Coordenação de Aperfeiçoamento de Pessoal de Nível Superior - Brasil (CAPES - FinanceCode 001).

\section{Conflicts of interest}

Authors declare no conflict of interest.

\section{References}

1. Jégu M. Subfamily Serrasalminae (Pacus and piranhas). In: Reis RE, Kullander SO, Ferraris CJ, editors. Check list of the freshwater fishes of South and Central America. Edipucrs. Porto Alegre. 2003.p. 182-196.

2. Dilma VR, Marcelo BC, Atila Maia da Rocha, et al. MPA. Ministério da Pesca e Aquicultura, Boletim estatístico da pesca e aquicultura: Brasil. 2011.

3. IBGE. Instituto Brasileiro de Geografia e Estatística. Produção da Pecuária Municipal 2016. IBGE, Rio de Janeiro. 2017.

4. Hashimoto DT, Senhorini JA, Foresti F, et al. Interspecific fish hybrids in Brazil: management of genetic resources for sustainable use. Rev Aquacult. 2012;4(2):108-118.

5. Woynárovich A, Van Anrooy R. Field guide to the culture of tambaqui (Colossomamacropomum, Cuvier, 1816). FAO Fisheries and Aquaculture Technical Paper No. 624. Rome. 2019.

6. Gomes LC, Simões LN, Araujo-Lima CARM. Tambaqui (Colossomamacropomum). In: Baldisserotto B, Gomes LC, editors. Espécies nativas para piscicultura no Brasil. 2010. 2a edição. UFSM, Santa Maria, pp. 175-204.
7. Nunes JRS, Liu S, Pértille F, et al. Large-scale SNP discovery and construction of a high-density genetic map of Colossomamacropomum through genotyping-by-sequencing. Sci Rep. 2017;7:46112.

8. Gonçalves RA, Santos CHA, Leitão CSS, et al. Genetic basis of Colossomamacropomumbroodstock: Perspectives for an improvement program. J World Aquacult Soc. 2019;50(3):633-644.

9. Hulata G. Genetic manipulations in aquaculture: a review of stock improvement by classical and modern technologies. Genetica. 2001;111(1-3):155-173.

10. Arai K, Fujimoto T. Chromosome manipulation techniques and applications to aquaculture, In: Wang H, Piferrer F, Chen S, editors. Sex Control in Aquaculture. John Wiley \& Sons, United Kingdon. 2018; p. 137-162.

11. Tiwary BK, Kirubagaran R, Ray AK. The biology of triploid fish. Rev Fish Biol Fisher. 2004;14(4):391-402.

12. Piferrer F, Beaumont A, Falguière JC, et al. Polyploid fish and shellfish: production, biology and applications to aquaculture for performance improvement and genetic containment. Aquaculture. 2009;293(34):125-156.

13. Almeida FL, Lopes JS, Crescencio R, et al. Early puberty of farmed tambaqui (Colossoma macropomum): Possible influence of male sexual maturation on harvest weight. Aquaculture. 2016;452(1): 224-232.

14. Dunham RA. Aquaculture and Fisheries Biotechnology: Genetic Approaches: 2nd edn. CABI Publishing, Oxfordshire. 2011.

15. Foresti F, Oliveira C, Almeida-Toledo LF. A method for chromosome preparations from large fish specimens using in vitro short-term treatment with colchicine. Experientia. 1993;49(9):810-813.

16. Howell WM, Black DA. Controlled silver-staining of nucleolus organizer regions with a protective colloidal developer: a 1-step method. Experientia. 1980;36(8):1014-1015.

17. Levan A, Fredga K, Sandberg AA. Nomenclature for centromeric position on chromosomes. Hereditas. 1964;52(2):201-220.

18. Almeida-Toledo LF, Foresti F, Toledo-Filho SA, et al. Cytogenetic studies in Colossomamitrei, C. macropomum and their interspecific hybrid. In: Tiews K, editor. Selection, Hybridization and Genetic Engeneering in Aquaculture. Berlin, 1987; p 189-195.

19. Nirchio M, Fenocchio AS, Swarça AC, et al. Cytogenetic characterization of hybrids offspring between Colossomamacropomum (Cuvier, 1818) and Piaractusbrachypomus (Cuvier, 1817) from Caicara del Orinoco, Venezuela. Caryologia. 2003;56(4):405-411.

20. Huergo GM, Zaniboni-Filho E. Triploidy induction in Jundiá, Rhamdiaquelen, through hydrostatic pressure shock. J Appl Aquaculture. 2006;18(4):45-57.

21. Goodpasture C, Bloom SE. Visualization of nucleolar organizer regions in mammalian chromosomes using silver staining. Chromosoma. 1975;53(1):37-50.

22. Miller OJ, Miller DA, Dev VG, et al. Expression of human and suppression of mouse nucleolus organizer activity in mouse-human somatic cell hybrids. Proc Natl Acad Sci. U S A. 1976;73(12):4531-4535.

23. Howell WM. Visualization of ribosomal gene activity: silver stains proteins associated with rRNA transcribed from oocyte chromosomes. Chromosoma. 1977;62:361-367.

24. Jordan G. At the heart of the nucleolus. Nature. 1987;329(6139):489-490.

25. Piferrer F, Cal RM, Álvarez-Blázquez B, et al. Induction of triploidy in the turbot (Scophthalmus maximus): I. Ploidy determination and the effects of cold shocks. Aquaculture. 2000;188(1-2):79-90. 
26. Piferrer F, Cal RM, Gómez C, et al. Induction of triploidy in the turbot (Scophthalmus maximus): II. Effects of cold shock timing and induction of triploidy in a large volume of eggs. Aquaculture. 2003;220(1-4):821831.

27. Chourrout D. Thermal induction of diploid gynogenesis and triploidy in the eggs of the rainbow trout (Salmo gairdneri Richardson). Reprod Nutr Dev. 1980;20(3A):727-733.

28. Hammed AM, Fashina-Bombata HA, Osinaike AO. The use of cold shock in inducing triploidy in African mud catfish (Clariasgariepinus). Afr J Biotechnol. 2010;9(12):1844-1847.

29. Almeida-Toledo LF, Bernardino G, Oliveira C, et al. Gynogenetic fish produced by a backcross involving a male hybrid (female Colossomamacropomum x male Piaractusmesopotamicus) and a female Piaractusmesopotamicus. Bol Téc CEPTA. 1996;9:31-37.

30. Hashimoto DT, Senhorini JA, Foresti F, et al. Genetic Identification of F1 and Post-F1 Serrasalmid Juvenile Hybrids in Brazilian Aquaculture. PloSOne. 2014;9:e89902.

31. Fernandes-Matioli FMC, Almeida-Toledo LF, Toledo-Filho SA Natural triploidy in the Neotropical species Gymnotuscarapo (Pisces: Gymnotiformes). Caryologia.1999;51(3-4):319-322.

32. Giuliano-Caetano L, Bertollo LAC. Karyotypic variability in Hoplerythrinusunitaeniatus (Pisces, Characiformes, Erythrinidae). Occurrence of natural triploidy. Rev Bras Genet. 1990;13:231-237.

33. Borin LA, Martins-Santos IC, Oliveira CA. A natural triploid in Trichomycterus davisi (Siluriformes, Trichomycteridae): mitotic and meiotic characterization by chromosome banding and synaptonemal complex analyses. Genetica. 2002;115(3):253-258.
34. Molina WF, Margarido VP, Galetti Jr PM. Natural triploidy in Leporinus cf. elongatus bearing sex chromosomes. Genet Mol Biol. 2007;30(3):567569.

35. Pansonato-Alves JC, Vicari MR, Oliveira C, et al. Chromosomal diversification in populations of Characidium cf. gomesi (Teleostei, Crenuchidae). J Fish Biol. 2011;78(1):183-194.

36. Machado SN, Ferreira-Neto M, Bakkali M, et al. Natural triploidy and B chromosomes in Astyanax scabripinnis (characiformes, characidae): A new occurrence. Caryologia. 2012;65(1):40-46.

37. Silva M, Matoso DA, Ludwig LAM, et al. Natural triploidy in Rhamdiaquelen identified by cytogenetic monitoring in Iguaçu basin, southern Brazil. Environ Biol Fishes. 2011;91(1):361-366.

38. Weiss LA, Zaniboni-Filho E. Survival of diploid and triploid Rhamdiaquelen juveniles in different ammonia concentrations. Aquaculture. 2009;298(1-2):153-156.

39. Weiss LA, Zaniboni-Filho E. Survival of diploid and triploid Rhamdiaquelen juveniles under different oxygen concentrations. J Appl Aquacult. 2010;22(1):30-38.

40. Vozzi PA, Sánchez S, Permingeat ED. Inducción de triploidíaen Rhamdiaquelen (Pisces, Pimelodidae). Boletim Instituto de Pesca. 2003;29(1):87-94.

41. Fracalossi DM, Meyer G, Santamaria FM, et al. Desempenho do jundiá, Rhamdiaquelen, e do dourado, Salminus brasiliensis, em viveiros de terra na região sul do Brasil. Acta Sci. 2004;26(3):345-352.

42. Silva FSD, Moreira RG, Orozco-Zapata CR, et al. Triploidy induction by cold shock in the South American catfish, Rhamdiaquelen (Siluriformes) (Quoy\&Gaimard, 1824). Aquaculture. 2007;272(1):S110-S114. 